\title{
SUSTAINABLE TOURISM DEVELOPMENT IN THE BACKWATERS OF SOUTH KERALA, INDIA: THE LOCAL GOVERNMENT PERSPECTIVE
}

\author{
Emilda K. JOSEPH*
}

Christ College, Mahatma Gandhi University, Idukki, Kerala, India, e-mail: emildahelloise@gmail.com

\author{
Tomy K. KALLARAKAL
}

School of Commerce, Finance and Accountancy, CHRIST (Deemed to be University), Bengaluru, Karnataka, India, e-mail: tomy.kk@christuniversity.in

Bindi VARGHESE

School of Business and Management, CHRIST (Deemed to be University), Bengaluru, Karnataka, India, e-mail: bindi.varghese@christuniversity.in

\author{
Jose K. ANTONY
}

Rajagiri College of Social Sciences (Autonomous), Kochi, Kerala, India, e-mail: josekantony@ rajagiri.edu

\begin{abstract}
Citation: Joseph, E.K., Kallarakal, T.K., Varghese, B., \& Antony J.K.. (2020). SUSTAINABLE TOURISM DEVELOPMENT IN THE BACKWATERS OF SOUTH KERALA, INDIA: THE LOCAL GOVERNMENT PERSPECTIVE. GeoJournal of Tourism and Geosites, 33(4spl), 1532-1537. https://doi.org/10.30892/gtg.334spl13-604
\end{abstract}

\begin{abstract}
Improper waste management continues to be a major challenge in the backwater destinations of South Kerala, India and the local government has been identified as a key player having a strong influence on sustainable tourism development initiatives in the destination. The study examines the major obstacles encountered while implementing sustainable tourism development practices in the backwater destinations of South Kerala, India. Qualitative data collected with the support of semi-structured interviews with top government officials of the Tourism Industry is used for the study. The findings from the study show that improper waste management affects sustainable tourism development in the backwater destinations, and that community involvement and community support are pre-requisites for implementing solid waste management practices in the backwater destinations of the state. The study also enlightens the roles of various stakeholders in waste management so as to develop a strong perspective of sustainable tourism development in the region.
\end{abstract}

Key words: sustainable tourism, sustainable tourism development, backwater tourism, waste management, community support, community involvement, perception.

\section{INTRODUCTION}

Backwaters of Kerala have garnered international interest through Houseboat Tourism that has emerged as the flagbearer of the Kerala Wetland Tourism Industry (Kokkranikal and Morrison, 2020). The geographical expanse of the backwaters has also resulted in a renewed interest in Backwater Tourism. It has met with great success in the state of Kerala in India, which in turn has led to the tremendous growth of tourism facilities in the region like houseboats, homestays, and resorts along the shores of the backwaters. Aggressive national and international marketing campaigns in Backwater Tourism create positive impacts on the monetary expansion and in the creation of jobs for local people. But the adverse impacts of Backwater Tourism are inevitable (Dileep, 2014). One way to address the problems is to develop a systematic plan to ensure sustainable and eco-friendly development in the backwater areas. This will resolve the multiple issues arising from the tourism activities in the wetlands (World Tourism Organization, 2012). Many researchers have also expressed the need for sustainable development in the backwater destinations of South Kerala. However, they always seem to ignore the top government officials' perspectives on the major obstacles of sustainable tourism development, especially those suitable for the three major backwater tourism regions of Alappuzha, Kollam, and Kottayam in South Kerala. According to Nikčević (2019) addressing sustainable tourism development programs in a destination requires the participation of various stakeholders. Among all these stakeholders, the local government is identified as a key player who has a strong influence on the sustainable tourism development initiatives in a destination. Understanding and identifying the problems and initiating the right actions will help them to propose appropriate solutions to tackle the difficulties and transform the concept of sustainable tourism development into a daily practice for the Tourism Industry in the backwaters of South Kerala.

The study aims to examine the major obstacles in implementing sustainable tourism practices from the perspective of top government officials by employing qualitative research techniques. Hence, the research question formulated for the study is, what are the major obstacles in implementing sustainable tourism development practices in the backwater destinations of South Kerala from the perspective of government officials? The paper offers an overview of the review of related literature based on a few criteria in the areas of sustainability, tourism, and destination management, connected with the research study. The methodology section of the paper focuses on the study area, and the techniques of data collection and analysis, which are followed by the findings, discussions and conclusion.

\section{LITERATURE REVIEWS}

\section{Sustainable Tourism Development}

Tourism destinations are always trying to practice and strive for sustainability. This process influences all aspects of tourism on a dayto-day basis. Mearns (2012) quoted, "nowadays people perceive themselves as an integral part of the environment because they are increasingly aware of the various activities that have a direct impact on the environment". At the same time, sustainable development has been recognized as a powerful tool for development of the human society and it plays a significant role in the conservation of resources in many parts of the world (Cristian et al., 2015). According to Hunter (1997) Sustainable Tourism is not a highly rigid framework but an

\footnotetext{
${ }^{*}$ Corresponding author
} 
adaptive paradigm that explains the varied approaches to suit different circumstances, and it also encompasses principles, policies, methods, and prescriptions that help to protect tourism development for the future. Sustainable Tourism refers to the ability of the society, the ecosystem and other existing similar systems to operate continuously towards an unanticipated future, while also ensuring that the key resources are not depleted (Janusz and Bajdor, 2013). Therefore a sustainable framework can balance environmental conservation with community development (Kimbu and Tichaawa, 2018). While emphasizing on the local environment, the host community, and the visitors, it also ensures to cater to the needs of all the three (Savage et al., 2004). Sustainable development is also one of the promising factors for resolving the negative impacts on the socio-cultural, economic, and environmental resources (Kimbu and Tichaawa, 2018).

Butler (1999) in his article, 'Sustainable Tourism: A State of the Art Review' clearly defines the origin and development of the concepts of Sustainable Tourism and Sustainable Tourism Development. The study points to the original definition of Sustainable Tourism Development which was proposed by the Brundland Commission in 1987, in 'Our Common Future' as 'the developments that meet the needs of the present without compromising on the ability of the future generations to meet their own needs.'

Angelevska and Rakicevik (2012) elaborated on the three aspects that were part of the concept of sustainable development, namely economic, environmental, and social or cultural aspects. Economic sustainable development provides frameworks for the cost-effective utilization of local resources while environmental sustainable development is more compatible with the needs of biological diver sity. Social or cultural sustainable development considers traditional cultural values to strengthen community development.

Sustainable Tourism should therefore be carefully designed to benefit the local community, respect the local culture, and protect the natural resources. The main considerations for Sustainable Tourism include stakeholder partnerships, community development, and sustainable benefits to conserve the resources. All these offer an important and promising mechanism for local communities to optimally utilize and take full advantage of the tourism resources (Angelevska and Rakicevik, 2012). Butowski (2014) in his study considers both Sustainable Tourism and Sustainable Development as a similar phenomenon and the study has been able to successfully renew res earch interest in Sustainable Tourism across the globe. The study also added that Sustainable Tourism was crucial for communities to develop and safeguard the cultural and authentic values of the tourism destinations, as tourism played a significant role in economic development by contributing to the employment opportunities and in the development of micro and medium enterprises. Prabhakaran et al., (2013) also explained that the major roadblocks and hindrances while implementing Sustainable Tourism Practices should be regularly and continuously analyzed to develop the form of tourism in any destination. Therefore, the future of the Sustainable Tourism Industry is a matter of great interest and concern for Backwater Tourism. The concept of Sustainable Tourism is the need of the hour and it has become a recognized goal for many forms of tourism conservation (Sakolnakorn et al., 2013).

\section{Backwaters of South Kerala}

Backwaters are wetlands where the rivers meet the sea or where freshwater mixes with seawater, and where tides occur (Cui et al., 2012). According to the Ramsar Convention in 1971, 'wetlands are areas of marsh, fen, peatland or water, whether natural or artificial, permanent or temporary, with water that is static or flowing, fresh, brackish or salty, including areas of marine water, the depth of which at low tide does not exceed more than six meters.' The backwaters of Kerala stretch over a total expanse of $1500 \mathrm{~km}$ across the districts of Alappuzha, Kottayam, Trivandrum, Kollam, Kozhikode, Kasaragod and Ernakulum. The backwaters have a network of more than 44 rivers, lagoons and lakes from the north to the south, and of the 29 major lakes on the backwaters, seven drains into the sea. The backwaters of South Kerala have gained international acclaim as Houseboat Tourism has emerged as the backbone of the Kerala Backwater Tourism Industry (Kokkranikal and Morrison, 2020). The backwaters of Alappuzha, Kumarakom and Kollam are the most popular on the tourist trail for backwater boat trips as they attract both international and national tourists in large numbers all around the year.

The largest backwater body in the state, the Vembanad Lake flows through Alappuzha and Kottayam districts, and this region is popularly known as Kumarakom while the second largest backwater lake is Ashtamudi and it flows through Kollam district. The longest and the most enchanting backwater experience is from Kollam to Alappuzha. The houseboats traditionally known as the kettuvalloms are traditional water boats that have been transformed into super-luxury houseboats offering a unique travel experience in Kerala for every visitor. Tourism activities in Kerala, especially in southern Kumarakom, are at their peak on the Vembanad Lake (Vincy et al., 2012). However, the region has been subjected to acute pressure due to numerous developmental activities and overutilization of resources. Population growth and industries are directly contributing to the loss of the natural ecosystem.

Numerous tourism facilities such as hotels and resorts are being built without considering the healthy preservation of the natural environment in the backwater destinations. Vincy et al. (2012) understood that in addition to the many resorts constructed on the shores of the lakes, the houseboats also contributed to the problems in the backwaters. Though the houseboats offered a wonderful means to experience the beauty of the backwaters, the current expansion of Backwater Tourism was highly unregulated. Asha et al. (2016) studied that Backwater Tourism was causing a lot of harm to the society and the environment. Most of the wetlands were facing a serious threat to their existence and these threats to their sustainability were mainly caused due to human actions.

Although houseboats play an integral role in Backwater Tourism, they are not completely suited for supporting tourism activities because of their physical and morphological attributes. It has been found that successful and scientific strategies have not yet been developed to overcome many of the problems caused by houseboats. The involvement of stakeholders in decision making is an important element in successful Backwater Tourism Management. Therefore, it has become imperative for the Backwater Tourism Industry to sustain its basic elements for the development of the destination across the three dimensions, namely social, economic, and environmental factors. The recent developments in Backwater Tourism have highlighted the importance of Sustainable Tourism Development as one of the most desirable forms of tourism development especially to preserve the natural, cultural and social values (Dileep, 2014). According to UNWTO, the tourism sector is now gearing up to resume its activities with the lessons learned in the aftermath of the COVID - 19 pandemic. And they have mentioned 'sustainability' to no longer be a niche element in the tourism sector but as the new norm for every nook and corner of the sector. It is in the hands of every stakeholder to transform tourism while it re-emerges in the year, revolving around sustainability. The time is now appropriate to advance towards a more economically, socially, and environmentally sustainable world. Hence the study highlights the ongoing challenges inherent in tackling the issues in Sustainable Tourism Development in the backwater regions of South Kerala.

\section{Perceptions of Government Officials on Sustainable Tourism Development}

The attitude of the stakeholders is of paramount importance in preserving and sustaining tourism products (Moral-cuadra et al., 2019). Perception can be understood as the stakeholders' attitudes towards opinions and reactions, and this perception on the environment can be understood to create a strong and long-standing relationship between themselves and their surrounding environment (Lee, 2013). Individual perceptions are governed by past experiences, present social circumstances, values, and beliefs (Kaoje et al., 
2017). However, this relationship is not as simple as the different factors that support the relationship (Buenrostro et al., 2015). Factors that influence the perceptions on benefits and costs of tourism include the level of participation, use of local resources and involvement in various activities (Núñez-tabales et al., 2016). The perception of government officials towards the environment, and their involvement and participation in tourism activities were the most important factors that influenced the behavior of the local community towards environmental improvement (Eshliki and Kaboudi, 2012). If the government officials were willing to involve and participate in various development strategies, then the tourism destinations exhibited the potential to improve their sustainability (Basiru et al., 2017).

The perception of the government officials influenced the destinations' values, beliefs, and successes (Kumar and Nandini, 2013), and their perception towards the impacts of tourism were also considered as significant aspects during the planning and policy-making stages (Aref et al., 2009). Strydom and Mangope (2019) also believed that for those destinations which completely depended on the Tourism Industry to sustain themselves, government officials played a key role in conserving sustainability and in influencing the attitude, perception, support and involvement of the local community. Therefore, understanding the perception of the government officials about the benefits and the costs of the tourism destinations can be considered as a strong indicator to measure the communities' perceptions on Sustainable Tourism. This also acts as an important factor in the development of tourism destinations.

\section{RESEARCH METHODOLOGY AND METHODS}

\section{Study Area}

The backwaters of South Kerala were selected as the research area for the study. Backwater Tourism has garnered a lot of success in the tourism sector of Kerala which has led to the tremendous growth of tourism facilities like houseboats, homestays, and resorts around the areas of the backwaters. With a network of more than 44 rivers, lagoons and lakes, the backwaters of Alappuzha, Kumarakom and Kollam are prominent on the tourist maps for backwater boat trips. The longest, the best and the most enchanting backwater experience is enjoyed on boat rides from Kollam to Alappuzha. The wide geographical expanse of the backwaters in the state has led to renewed interest in Backwater Tourism. However, the negative impacts of Backwater Tourism are inevitable. One way to overcome the problems is to develop a systematic plan so as to ensure sustainable and eco-friendly developments in the backwater destinations.

\section{Data Collection}

To obtain more authentic and useful information from the study, an Interview Guide was used as a research instrument and face-to-face interviews were conducted with the top government officials in the Department of Tourism in the backwater regions of South Kerala, India. The Interview Guide was first written in English and it was later translated into Malayalam, the local language of the state. A professional translator and a language editor took part in the data collection process in order to assure the reliability of the translated information. Further, it was assessed for content validity by academic and industry experts prior to the commencement of the actual data collection.

The Interview Guide had three parts; the first set of questions were related to the socio-demographic profile of the respondents, the second set of questions helped to explore the tourism development practices and the changes in the backwater region, and the third set of questions helped to explore the impacts of tourism. The respondents for the study were selected from the Department of Tourism in the backwater regions of Kerala. Top government officials were considered as the participants, and as they were less in number, e very other member (5) was selected for the interview. A Census Survey Method was employed. The interviews were carried out between August and December 2018. Table 1 presents the Profiles of the Respondents.

Table 1. Profiles of the Respondents

\begin{tabular}{|l|l|l|}
\hline Name & \multicolumn{1}{|c|}{ Profile } & \multicolumn{1}{c|}{ Area } \\
\hline Respondent 1 & Information Officer, Tourism Department & Alappuzha \\
\hline Respondent 2 & Secretary, District Tourism Promotion Council & Kumarakom, Kottayam \\
\hline Respondent 3 & Director, Responsible Tourism Initiatives & Kollam \\
\hline Respondent 4 & Secretary, District Tourism Promotion Council & Kumarakom, Kottayam \\
\hline Respondent 5 & Secretary, Department of Tourism & \\
\hline
\end{tabular}

\section{Analysis}

A professional translator and a language editor transcribed the interviews. By focusing on previous studies, the interview questions were independently examined so as to develop categories and clusters. This study employed a cross-case analysis approach by using NVIVO Version 12 in order to understand the major obstacles in Sustainable Tourism Development in the backwater regions of Kerala. Cross Case Analysis is a research technique in which the variations and similarities of events, activities, cases, and processes are compared so as to understand the meaning of single or multiple case studies so as to produce desired outcomes. It organizes the cases in to tables and graphs (Cruzes et al., 2015). The analysis consisted of five phases. In the first phase, each interview was considered as an individual case study, and a new Nvivo Project was created with each case study from the transcripts by including all the data from the trans cripts. Text sources were coded with nodes (themes) and this was then organized into hierarchies in order to understand the broader and narrower concepts. This helped to cluster the concepts and to exhibit the relationships between the themes. In the second phase, the data that was not of primary interest to the study was eliminated and each case study was then compared and discussed. The focused codes that directly addressed the study were developed in the third phase. In the fourth phase, the individual findings were compared and discuss ed, and in the last phase, the theoretical concepts that emerged from the raw data were categorized under different themes. Exemplary quo tations were also included for all the themes. Based on the context of the study, the coding process is illustrated as shown in Table 2.

\section{FINDINGS AND DISCUSSIONS}

\section{The main changes in the Backwater Tourism Destinations}

Sustainable ways of developing tourism offer the chance to support an ecosystem to operate continuously in an undefined future without any resource depletion (Sumarmi et al., 2020). According to the participants' answers to the question, "what are the main changes you have seen in the backwaters due to the tourism activities over the last decade?" majority of the respondents said that waste management was one of the main problems faced in the backwater destinations due to the increased movements of unauthorized houseboats. As a result of sewage and other forms of pollution, the backwaters have become highly contaminated and the quanti ty of fish in the waters has reduced considerably. This has resulted in severe damage to the backwater ecosystems and it has also drastically affected the lives of the local people who depend on fishing in these areas. "There are innumerable houseboats that commute through the 
backwaters which are more than what the backwaters can accommodate. If the situation is allowed to continue for the next two decades, the condition of Vembanad Lake will worsen. In recent time there was an incident wherein, dead fish was found floating on the water and the main reason for this was pollution. I would mainly point towards houseboats' wastes." (Respondent 3)

Table 2.The Coding Process

\begin{tabular}{|c|c|c|}
\hline Exemplary Quotations & \begin{tabular}{|c|} 
Code \\
\end{tabular} & Theme \\
\hline $\begin{array}{l}\text { "The primary reason for Vembanad Lake to be polluted from tourism is due to } \\
\text { waste from houseboats." (Respondent } 3 \text { ) }\end{array}$ & $\begin{array}{l}\text { Increase in waste management problems } \\
\text { Increase in pollution }\end{array}$ & \multirow{4}{*}{$\begin{array}{l}\text { Major changes in the } \\
\text { backwater tourism } \\
\text { destinations }\end{array}$} \\
\hline $\begin{array}{l}\text { "Backwater tourism destinations are environmentally degraded and physically } \\
\text { polluted." (Respondent 4) }\end{array}$ & Environmental degradation & \\
\hline $\begin{array}{l}\text { "Due to sewage and other forms of pollution, backwaters have become highly } \\
\text { polluted and the amount of fish in them has been reduced substantially." } \\
\text { (Respondent } 3 \text { ) }\end{array}$ & $\begin{array}{l}\text { Increase in pollution } \\
\text { Reduction in fish wealth }\end{array}$ & \\
\hline $\begin{array}{l}\text { "The major hindrance in implementing tourism development projects in } \\
\text { Alappuzha is the intervention of the local community; more specifically, trade } \\
\text { unions and party-based interventions. Only if there is unity among the tourism } \\
\text { stakeholders will development initiatives be practical." (Respondent 1) }\end{array}$ & No initiatives from tourism stakeholders & \\
\hline $\begin{array}{l}\text { "There are innumerable houseboats that commute through the backwaters which } \\
\text { are more than what the backwaters can accommodate. Most of them are } \\
\text { unregistered houseboats." (Respondent } 4 \text { ) }\end{array}$ & $\begin{array}{l}\text { Increase in the number of houseboats } \\
\text { Unregistered houseboats }\end{array}$ & \multirow{5}{*}{$\begin{array}{l}\text { Major issues in the } \\
\text { backwater tourism } \\
\text { destinations }\end{array}$} \\
\hline $\begin{array}{l}\text { "There are no particular and strict rules and regulations for houseboat operators. } \\
\text { They conduct their services the way they please." (Respondent 3) }\end{array}$ & No strict rules for houseboat operations & \\
\hline $\begin{array}{l}\text { "The backwater tourism destinations of Alappuzha still follow the age-old } \\
\text { practices of the cleaning process. Presently there are no waste management } \\
\text { initiatives and the Department of Tourism is yet to introduce a master plan to } \\
\text { address the problems of waste management." (Respondent 1) }\end{array}$ & $\begin{array}{l}\text { Old traditions of waste management } \\
\text { No new waste management initiatives }\end{array}$ & \\
\hline $\begin{array}{l}\text { "The common rule is that all the houseboats should have STP plants, but most of } \\
\text { the washroom wastes from the houseboats are discharged directly into the } \\
\text { backwaters, and there are no skilled workers to handle the waste materials from } \\
\text { the houseboats." (Respondent 2) }\end{array}$ & $\begin{array}{l}\text { Improper waste management } \\
\text { No adequate manpower } \\
\text { Dumping of waste from houseboats }\end{array}$ & \\
\hline $\begin{array}{l}\text { "The attitudes of the local communities are a huge roadblock whenever the } \\
\text { Department of Tourism tries to implement any tourism development projects." } \\
\text { (Respondent } 1 \text { ) }\end{array}$ & $\begin{array}{l}\text { The attitude of the local community } \\
\text { No support and involvement from the local } \\
\text { community }\end{array}$ & \\
\hline $\begin{array}{l}\text { "The Department of Tourism can play the role of a moderator in supporting } \\
\text { tourism development in the area by offering financial support." (Respondent 4) }\end{array}$ & $\begin{array}{l}\text { Financial support } \\
\text { Facilitator }\end{array}$ & \multirow{7}{*}{$\begin{array}{l}\text { Mitigating measures to } \\
\text { reduce the negative } \\
\text { impacts }\end{array}$} \\
\hline $\begin{array}{l}\text { "Gradually houseboats can shift to solar engines which would help to a great } \\
\text { extend in overcoming the problems of pollution. If they can run on solar } \\
\text { engines, pollution from petrochemicals can be reduced, overdependence on fuel } \\
\text { can be avoided, more number of sewage treatment plants can be set up, plastic } \\
\text { bottles can be banned, cloth bags can be provided and awareness programs can } \\
\text { be organized for the local community." (Respondent 5) }\end{array}$ & $\begin{array}{l}\text { Solar energy } \\
\text { Solar-powered engines } \\
\text { Sewage treatment plants } \\
\text { Cloth bags } \\
\text { Ban on plastic below the stipulated micron }\end{array}$ & \\
\hline $\begin{array}{l}\text { "The Department of Tourism has implemented Global Positioning Systems } \\
\text { (GPS) for all registered houseboats." (Respondent 1) }\end{array}$ & GPS Monitoring System & \\
\hline $\begin{array}{l}\text { "More opportunities can be provided to the local people by implementing } \\
\text { controlled waste management programs like bio-toilets in the houseboats, and } \\
\text { plastic waste dumping and collection units in various areas." (Respondent } 4 \text { ) }\end{array}$ & $\begin{array}{l}\text { All houseboats to implement Sewage } \\
\text { Treatment Plants } \\
\text { More opportunities for the local community }\end{array}$ & \\
\hline $\begin{array}{l}\text { "Training programs to collect wastes from the canals will be offered. This will } \\
\text { prevent the waste from entering into the backwaters directly and hence it can be } \\
\text { controlled." (Respondent } 4 \text { ) }\end{array}$ & Training & \\
\hline $\begin{array}{l}\text { "As a part of promoting Sustainable Tourism, the Department of Tourism is in } \\
\text { the process of implementing new rules in order to classify houseboats based on } \\
\text { Green Environment Certifications. The guidelines for this are yet to be drafted. } \\
\text { But once implemented, the strict rules and regulations will put an end to the } \\
\text { operations of those houseboat operators without licenses." (Respondent 5) }\end{array}$ & Green Environment Certification & \\
\hline $\begin{array}{l}\text { "At present, there is a 'mobile barge' in Kumarakom, Kottayam for handling the } \\
\text { wastes in the backwaters. Unfortunately, it is about } 2 \text { to } 2.5 \mathrm{~km} \text { from the main } \\
\text { cruise routes of the houseboats. The houseboat operators are unwilling to travel } \\
\text { this far to dump their wastes while giving up on the cruises. Therefore the only } \\
\text { remedial measure to overcome this problem is to introduce a mobile barge, like } \\
\text { the one in Kumarakom." (Respondent 5) }\end{array}$ & Mobile barge & \\
\hline
\end{tabular}

\section{The major issues facing Backwater Tourism today}

According to the participants' responses to the question, "what are the major issues that Backwater Tourism is facing today?" majority of the respondents said that there were innumerable houseboats that commuted through the backwaters, which was more than what the waters could accommodate. As Respondent 3 stated earlier, if this situation is allowed to continue in the future, the condition of Vembanad Lake would worsen. Majority of the houseboats are also unregistered. The Department of Tourism can impose very heavy fines on the registered houseboats for irregularities in waste management, but no action can be taken against the unregistered houseboats. Two kinds of wastes are produced from all the houseboats, namely, solid and plastic wastes. The common rule is that all the houseboats must have a Sewage Treatment Plant but most of the washroom wastes from the houseboats are dumped directly into the backwaters and are not brought back to the shore to be treated in the sewage plants. Similarly, respondents also pointed out that there were no proper rules and regulations in place for houseboat operations. Houseboat operators conduct their services the way they please. Though there are many houseboats registered under the local administrative bodies known as the village panchayaths, many of the other houseboats operate without possessing valid and 
proper licenses. To add on to the challenge, the authorities have no count of the boats that move on the backwaters, and how many of them are actually complying with the government regulations. The pollution affecting the backwater regions can be controlled only through handin-hand coordination between the houseboat operators, the panchayaths and the local communities. This is therefore the need of the hour because without clean backwaters there would be no safe and peaceful lives for the local communities.

"The major issue in Backwater Tourism is the presence of a large number of houseboats without proper licenses. Many people start the houseboat business by borrowing huge amounts of money from the banks. To make an easy and quick profit, the houseboat operators are forced to provide services without valid and complete licenses. There is also no proper mechanism in place to manage the wastes from the houseboats, with many operators directly discarding the waste into the backwaters. This is the biggest difficulty being faced as it directly harms the backwaters, and without clean backwaters, there would be no life for the local community" (Respondent 3)

\section{Mitigating measures to reduce the negative impacts}

The Department of Tourism has to play the role of a strong moderator in order to support the development of tourism in the backwater regions of Kerala. The concept of Sustainable Tourism can never be possible without the active support of the local community, especially in a place of backwaters (Dileep, 2014). The government has its own limitations as local community members can raise major issues and objections against the plans proposed by the government institutions.

"Whenever developmental plans are proposed, major issues are raised by the local community members. Their attitude is to cause hindrance whenever the Department of Tourism tries to implement any development project. Therefore without the active support of the local community members, the department will not be able to bring about a positive change in the region" (Respondent 1).

Though the local community members were not very supportive in the past, in recent times with the introduction of Responsible Tourism initiatives, they have become more open and receptive to the proposed development programs. In addition to the community support, few other measures by which the region can overcome many of the existing problems could be through the use of solar energy, by implementing sewage treatment plants, by enforcing green environment certifications, and mandatory and clear regulations so as to treat the wastes from the houseboats, and by introducing statutory and strict licenses for houseboats. "The more important options a re solar energy and sewage treatment plants. There should be strict regulations enforced to treat the wastes, in such a manner that only when the plan is submitted will the licenses be issued for the houseboats to operate" (Respondent 3).

Figure 1 represents a comprehensive diagram which illustrates the major obstacles in the development of Sustainable Tourism in the backwater destinations of South Kerala.

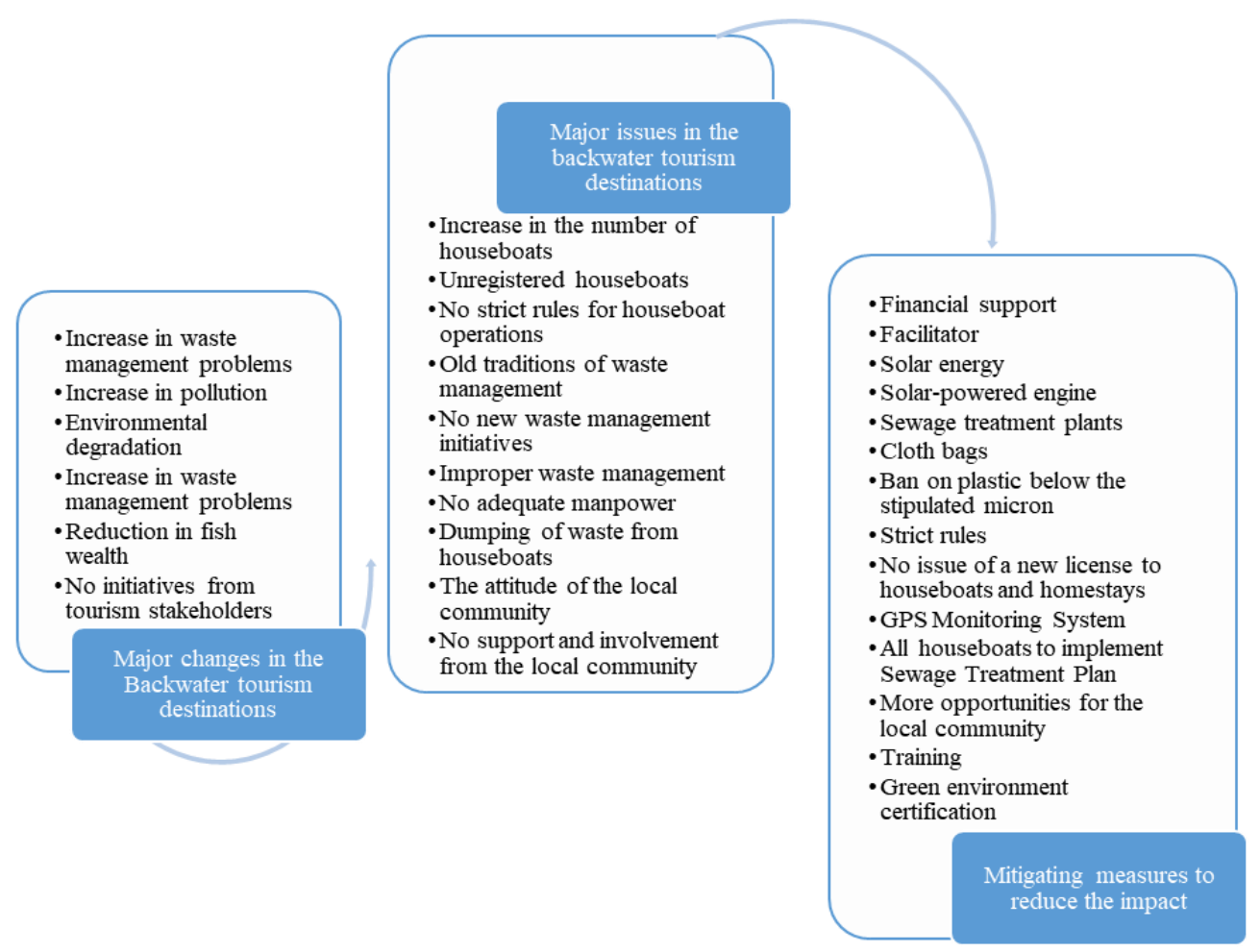

Figure 1. Major obstacles in the development of Sustainable Tourism in the backwater destinations of South Kerala

\section{CONCLUSION, LIMITATIONS AND SCOPE FOR FURTHER RESEARCH}

In conclusion, improper waste management is the biggest challenge in the backwater tourism destinations of Kerala. The study was able to suggest that improper waste management affected Sustainable Tourism Development in the backwater destinations and it also emphasized the role of various stakeholders in waste management that reflected a strong perspective of Sustainable Tourism Development. Reddy (2020) has further explained the importance of complete participation of different stakeholders in solid waste management because this process is a continuous maintenance activity and it can turn out to be a learning experience for everyone involved in the solid waste management program. Therefore, involvement and support of stakeholders are pre-requisites for implementing efficient solid waste management practices in the backwater destinations of Kerala. It will also offer many benefits to the stakeholders by providing a steady source of income and in uplifting the standards of living in the backwater destinations. The factors that can influence the perception of costs and benefits include the level of stakeholder participation, the use of local resources, and the involvement in various tourism development activities. The intensity of these factors can vary depending on the stakeholders' perceptions on the impact, which could either be positive or negative (Núñez-tabales et al., 2016). 
The study addressed two important gaps in the literatures on Backwater Tourism. Firstly, it enlightened the stakeholders about the existing challenges in Sustainable Tourism Development in the backwater destinations of Kerala. Secondly, the results confirmed that stakeholder support is imperative for Sustainable Tourism Development in the backwater regions. If the stakeholders are willing to involve and participate in waste management strategies and programs, then the tourism destinations will be able to develop the potential to improve sustainability (Basiru et al., 2017). Stakeholders in the backwater regions can develop programs, activities, and strategies that can help to enhance benefits and simultaneously reduce costs of Sustainable Tourism. Despite the suggestions and recommendations, this study had several limitations that can be addressed through further research. The study focused only on responses from the to $\mathrm{p}$ officials in the Department of Tourism at the backwater destinations of South Kerala. Other stakeholders in these destinations might have different opinions and disagreements about Sustainable Tourism practices and development initiatives. The study also focused on only a few of the major obstacles in Sustainable Tourism Development in the backwater destinations of South Kerala, while there are actually several other issues and challenges related to the backwater tourism destinations. Future research can consider the potential effect of a similar study across a wider spectrum. More research can also be carried out in order to understand the perception of local communities who might be directly or indirectly involved in the development of tourism in such destinations.

\section{REFERENCES}

Angelevska-Najdeska, K., \& Rakicevik, G. (2012). Planning of Sustainable Tourism Development. Procedia - Social and Behavioural Sciences, 44, 210-220. https://doi.org/10.1016/j.sbspro.2012.05.022

Aref, F., \& Gill, S.S. (2009). Community Perceptions toward Economic and Environmental Impacts of Tourism on Local Communities. Asian Social Science, 5(7), 130-137. https://doi.org/10.5539/ass.v5n7p130

Asha, C.V., Retina, I.C., Suson, P.S., \& Bijoy, N.S. (2016). Ecosystem analysis of the degrading Vembanad wetland ecosystem, the largest Ramsar site on the South West Coast of India - Measures for its sustainable management. Regional Studies in Marine Science, 8(3), 408-421. https://doi.org/10.1016/j.rsma.2016.06.003

Basiru, H.A., Yacob, M.R., Radam, A., \& Manaf, L.A. (2017). Households' Levels of Awareness, Perception, and Attitude towards Improved Solid Waste Collection Services in Kano. IOSR Journal of Humanities and Social Science, 22(9), 24-36. https://doi.org/10.9790/0837-2209122436

Buenrostro, O., Márquez, L., \& Ojeda, S. (2014). Environmetal perception of solid waste management in the municipalities of Patzcuaro Region, Mexico. Environmental Engineering and Management Journal, 13(12), 3097-3103. https://doi.org/10.30638/eemj.2014.348

Butler, R.W. (1999). Sustainable tourism: A state-of-the-art review. Tourism Geographies, 1(1), 7-25. https://doi.org/10.1080/14616689908721291

Butowski, L. (2014). Sustainable Tourism - A Model Approach. In Visions for Global Tourism Industry - Creating and Sustaining Competitive Strategies (pp. 1-20). University of Lodz, Poland. https://doi.org/10.5772/37718

Cristian, D., Maria, L., Artene, A., \& Duran, V. (2015). The components of sustainable development - a possible approach. Procedia Economics and Finance, 26(15), 806-811. https://doi.org/10.1016/S2212-5671(15)00849-7

Cruzes, D.S., Dybå, T., Runeson, P., \& Höst, M. (2015). Case studies synthesis: a thematic, cross-case, and narrative synthesis worked example. Empirical Software Engineering, 20(6), 1634-1665. https://doi.org/10.1007/s10664-014-9326-8

Cui, M., Zhou, J.X., \& Huang, B. (2012). Procedia Environmental Benefit evaluation of wetlands resource with different modes of protection and utilization in the Dongting Lake region. Procedia Environmental Sciences, 13, 2-17. https://doi.org/10.1016/j.proenv.2012.01.001

Eshliki, S.A., \& Kaboudi, M. (2012). Community Perception of Tourism Impacts and Their Participation in Tourism Planning : A Case Study of Ramsar, Iran. Procedia - Social and Behavioural Sciences, 36, 333-341. https://doi.org/10.1016/j.sbspro.2012.03.037

Hunter, C. (1997). Sustainable tourism as an adaptive paradigm. Annals of Tourism Research, 24(4), 850-867. https://doi.org/10.1016/S0160-7383(97)00036-4

Janusz, G.K., \& Bajdor, P. (2013). Towards to Sustainable Tourism Framework, Activities and Dimensions. Procedia Economics and Finance, 6(13), 523529. https://doi.org/10.1016/S2212-5671(13)00170-6

Kaoje, A.U., Sabir, A.A., Yusuf, S., Jimoh, A.O., \& Raji, M.O. (2017). Residents' perception of solid waste disposal practices in Sokoto, Northwest Nigeria African Journal of Environmental Science and Technology, 11(February), 94-102. https://doi.org/10.5897/AJEST2014.1791

Kimbu, A.N., \& Tichaawa, T.M. (2018). Sustainable development goals and socio-economic development through tourism in central Africa: Myth or reality. GeoJournal of Tourism and Geosites, 23(3), 780-796. https://doi.org/10.30892/gtg.23314-328

Kokkranikal, J., \& Morrison, A. (2020). Entrepreneurship and sustainable tourism: the houseboats of Kerala. Tourism and Hospitality Research, 4(1), 7-20. https://doi.org/10.1177/146735840200400102

Kumar, M., \& Nandini, N. (2013). Community attitude, perception and willingness towards solid waste management in Bangalore city, Karnataka, India. Internal Journal of Environmental Sciences, 4(1), 87-95. https://doi.org/10.6088/ijes.2013040100009

Lee, T.H. (2013). Influence analysis of community resident support for sustainable tourism development. Tourism Management, 34, 37-46. https://doi.org/10.1016/j.tourman.2012.03.007

Mearns, K.F. (2012). Lessons from the application of sustainability indicators to community-based ecotourism ventures in Southern Africa. African Journal of Business Management, 6(26), 7851-7860. https://doi.org/10.5897/AJBM11.2581

Moral-Cuadra, S., Orgaz-Agüera, F., \& Cañero-Morales, P.M. (2019). Attitude towards border tourism and its relationship with visitor satisfaction and loyalty. GeoJournal of Tourism and Geosites, 25(2), 609-622. https://doi.org/10.30892/gtg.23314-328

Dileep, M.R. (2014). Fluid Destination: Innovative, but who will protect it. Spotlight on Sustainable Tourism, (13), $23-26$.

Nikčević, J. (2019). Strengthening the role of local government to ensure sustainable development of the cruise sector : The case of Kotor. Marine Policy, 109, 1-12. https://doi.org/10.1016/j.marpol.2019.103693

Núñez-tabales, J.M., Canalejo, C., María, A., Tabales, N., Julia, M., Cañizares, S., \& María, S. (2016). Local Community Perceptions on Tourist Impacts and Associated Development: A Case Study on Sal and Boa Vista Islands A Case Study on Sal and Boa Vista Islands. Mediterranean Journal of Social Science, 383-394. https://doi.org/10.5901/mjss.2016.v7n1s1p383

Prabhakaran, S., Nair, V., \& Ramachandran, S. (2013). Marine waste management indicators in a tourism environment: Exploring possibilities for Semporna District, Sabah. Worldwide Hospitality and Tourism Themes, 5(4), 365-376. https://doi.org/10.1108/WHATT-03-2013-0013

Reddy, H. (2020). Stakeholder's involvement towards sustaining ecotourism destinations : the case of social entrepreneurship at Stakeholder's involvement towards sustaining ecotourism destinations: The case of social entrepreneurship at Mangalajodi. GeoJournal of Tourism and Geosites, 29 , 636-648. https://doi.org/10.30892/gtg.29220-495

Sakolnakorn, T.P.N., Naipinit, A., \& Kroeksakul, P. (2013). Sustainable tourism development and management in the Phuket province, Thailand. Asian Social Science, 9(7), 75-84. https://doi.org/10.5539/ass.v9n7p75

Savage, V.R., Huang, S., \& Chang, T.C. (2004). The Singapore River thematic zone: Sustainable tourism in an urban context. Geographical Journal, 170(3), 212-225. https://doi.org/10.1111/j.0016-7398.2004.00121.x

Strydom, A.J., \& Mangope, D. (2019). Making community-based tourism sustainable: Evidence from the free state province, south Africa. GeoJournal of Tourism and Geosites, 24(1), 7-18. https://doi.org/10.30892/gtg.24101-338

Sumarmi, Kurniawati, E., \& Aliman, M. (2020). Community based tourism (CBT) to establish blue economy and improve public welfare for fishing tourism development in Klatak beach, Tulungagung, Indonesia. Geo Journal of Tourism and Geosites, 31(3), 979-986. https://doi.org/10.30892/gtg.3

Vincy, M.V, Rajan, B., \& Kumar, P. (2012). Water Quality Assessment of a Tropical Wetland Ecosystem with Special Reference to Backwater Tourism, Kerala, South India. International Research Journal of Environment Sciences, 1(5), 62-68.

*** World Tourism Organisation. (2020, May 28). UNWTO launches global guidelines to reopen tourism [Press release] https://webunwto.s3.eu-west1.amazonaws.com/s3fs-public/2020-06/20060-One-Planet-EN.pdf

*** World Tourism Organization. (2012). Destination Wetlands - Supporting sustainable tourism, UNWTO, Madrid, https://doi.org/10.18111/9789284414697 